\title{
Uncertainties in climate change projections and regional downscaling in the tropical Andes: implications for water resources management
}

\author{
W. Buytaert ${ }^{1}$, M. Vuille ${ }^{2}$, A. Dewulf ${ }^{3}$, R. Urrutia ${ }^{4}$, A. Karmalkar ${ }^{5}$, and R. Célleri ${ }^{6}$ \\ ${ }^{1}$ Imperial College London, Civil and Environmental Engineering, London, UK \\ ${ }^{2}$ Univ. at Albany, State Univ. of New York, Dept. of Atmospheric and Environmental Sciences, Albany, USA \\ ${ }^{3}$ Wageningen Univ., Public Administration and Policy Group, Wageningen, The Netherlands \\ ${ }^{4}$ Univ. Austral de Chile, Laboratorio de dendrocronología, Valdivia, Chile \\ ${ }^{5}$ Univ. of Massachusetts Amherst, Climate System Research Center, Amherst, USA \\ ${ }^{6}$ Univ. de Cuenca, Centro para el Análisis de Sistemas Naturales, Cuenca, Ecuador
}

Received: 27 February 2010 - Published in Hydrol. Earth Syst. Sci. Discuss.: 11 March 2010

Revised: 25 June 2010 - Accepted: 28 June 2010 - Published: 15 July 2010

\begin{abstract}
Climate change is expected to have a large impact on water resources worldwide. A major problem in assessing the potential impact of a changing climate on these resources is the difference in spatial scale between available climate change projections and water resources management. Regional climate models (RCMs) are often used for the spatial disaggregation of the outputs of global circulation models. However, RCMs are time-intensive to run and typically only a small number of model runs is available for a certain region of interest. This paper investigates the value of the improved representation of local climate processes by a regional climate model for water resources management in the tropical Andes of Ecuador. This region has a complex hydrology and its water resources are under pressure. Compared to the IPCC AR4 model ensemble, the regional climate model PRECIS does indeed capture local gradients better than global models, but locally the model is prone to large discrepancies between observed and modelled precipitation. It is concluded that a further increase in resolution is necessary to represent local gradients properly. Furthermore, to assess the uncertainty in downscaling, an ensemble of regional climate models should be implemented. Finally, translating the climate variables to streamflow using a hydrological model constitutes a smaller but not negligible source of uncertainty.
\end{abstract}

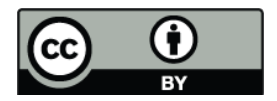

Correspondence to: W. Buytaert (w.buytaert@imperial.ac.uk)

\section{Introduction}

\subsection{Climate downscaling in mountain environments}

It is expected that global climate change will have a strong impact on water resources in many regions of the world (Bates et al., 2008). Higher temperatures are likely to increase evapotranspiration and therefore the atmospheric water vapour content. This may result in changes in large-scale precipitation patterns and the frequency of extreme events. The changes in evapotranspiration and the timing and intensity of precipitation are expected to strongly affect various types of water resources, particularly soil moisture, streamflow, and groundwater storage. Understanding the implications of climate change on these hydrological processes is of utmost importance for long-term and sustainable water resources planning.

The output of General Circulation Models (GCMs) is usually combined with hydrological models to translate the changes in atmospheric diagnostics to variables that are of direct relevance for water resources management, such as streamflow in individual catchments. However, the coupling of GCMs with hydrological models is challenging for various reasons. A main problem is the difference in spatial scale between global climate projections and water resources management. Due to limitations in data and computing power, GCMs are typically run on grid cells with a size of several $100 \mathrm{~km}$. As such, they smooth out local gradients in precipitation and temperature. However, for many

Published by Copernicus Publications on behalf of the European Geosciences Union. 
local hydrological processes these gradients are very important, and therefore further downscaling of climate projections is necessary (Buytaert et al., 2009).

The need for downscaling is particularly urgent for mountainous regions. Mountain regions provide important environmental services, such as water supply for adjacent, drier lowlands (Viviroli et al., 2010), but they are also particularly fragile to environmental change. Many of the meteorological, hydrological and biological processes in mountain areas are characterised by strong spatial gradients that can be easily perturbed.

At the same time, climate models predict a stronger effect of global warming in mountain regions compared to lowlands, due to a decreasing lapse rate (Still et al., 1999; Bradley et al., 2006; Urrutia and Vuille, 2009). Many of them are also expected to experience longer or stronger dry seasons (Beniston, 2003). The combination of a fragile ecosystem and an amplified climate change illustrates the potentially dramatic effect of global change on mountain areas and their importance for society. In these regions, the projections of GCMs are of limited value, and appropriate downscaling techniques should be applied to provide climate change information needed to drive hydrological models

Although many methods for disaggregation of large scale climate projections have emerged in the scientific literature (for an overview see e.g., Maraun et al., 2010), very few of these methods have been implemented in complex regions such as tropical mountain areas. The application of statistical downscaling methods is hindered by the lack of longterm precipitation records needed to fit statistical models of precipitation occurrence and amount. Additionally, the density of rain gauges is generally low. In the Ecuadorian Andes, for instance, the average density of rain gauges above $2500 \mathrm{~m}$ altitude is around 1 per $220 \mathrm{~km}^{2}$. This is just within the recommended minimum densities of non-recording precipitation stations $\left(100-250 \mathrm{~km}^{2}\right.$ per raingauge, World Meteorological Organisation, 1995), but insufficient to capture local gradients (Buytaert et al., 2006b; Célleri et al., 2007). Additionally, the location of these rain gauges is strongly biased towards the lower, more densely populated areas. In the upper Andean wet- and grasslands which constitute the major water supply areas, rain gauge density is much lower.

The implementation of regional climate models (RCMs) constitutes an alternative to statistical downscaling methods. These models operate at a typical resolution of $50 \mathrm{~km}$ or lower, and can capture the spatiotemporal variability of climate in much greater detail than GCMs. By providing more realistic simulations of present and future climate change in the Andes compared to coarser resolution GCMs, the RCMs can help providing better understanding of the impact these changes will have on Andean ecosystems and streamflow. RCMs are based on the same model physics as the driving GCM and therefore do not require a dense observational network as it is needed for statistical downscaling. However, careful model validation with observational data is still a nec- essary prerequisite to ensure that the RCMs accurately portray present-day spatiotemporal climate variability, in particular along mountain ranges such as the Andes, where orography strongly affects seasonal distributions of precipitation. RCMs have been used successfully for climate change studies over South America (e.g., Marengo et al., 2009; Soares and Marengo, 2009), but their application over the Andes is still in its early stages (Urrutia and Vuille, 2009). A major drawback of RCMs is that they are computationally expensive and rather complex to implement. Therefore, they are typically not run using the entire range of available AR4 models but simulations are based on just one or two driving GCMs. This significantly complicates uncertainty assessments. Model structural deficiencies, and errors in the forcing data and parameterization can also propagate from the driving GCM to the RCM and increase uncertainties. This makes it imperative to assess the value of RCMs for impact assessment on a case by case basis.

This paper aims at evaluating the usefulness of the regional climate model PRECIS and regional climate models in general for water resources management in the Ecuadorian Andes. PRECIS was previously implemented for tropical South America by Urrutia and Vuille (2009). Here we evaluate the control simulation carried out by PRECIS and compare its performance with the models included in the IPCC Third and Fourth Assessment Report (TAR and AR4, IPCC, 2001, 2007). In a second part of the study, the GCM results are routed through a hydrological model to assess the uncertainty in future discharge predictions, and to evaluate the relative impact of the uncertainty of the climate projections compared to the hydrological model.

\section{Climate change in the tropical Andes}

The concern regarding water resources in the Andes is reflective of the rapidly changing climate throughout the region. This is most notable in observations of near-surface temperature, which show an increase of $0.7^{\circ} \mathrm{C}$ over the past seven decades (1939-2006, Vuille et al., 2008). Of the last 20 years only two (1996 and 1999) were below the long term (1961-1990) average. Analyses of changes in freezing level height (FLH) over the American Cordillera and the Andes, based on the NCEP-NCAR reanalysis data show an increase of $73 \mathrm{~m}$ between 1948 and 2000 and of $53 \mathrm{~m}$ between 1958 and 2000, a period for which the data are considered more reliable (Diaz et al., 2003). The notion that warming will be exacerbated at the highest elevations as suggested by GCM results is hard to verify due to the lack of long and reliable observational records. However, recent reports from the Andes of Peru, which show that daily maximum temperatures now rise well above the freezing temperature between October and May even at elevations as high as $5680 \mathrm{~m}$ certainly seem to support this assumption (Bradley et al., 2009). 
Such changes in temperature are sufficient to cause significant shifts in the ranges of native species and water availability.

Changes in precipitation over the 20th century have been less notable but Vuille et al. (2003) found a tendency for increased precipitation north of $11^{\circ} \mathrm{S}$, in Ecuador, while in southern Peru and along the Peru/Bolivia border most stations indicate a precipitation decrease. These results were later confirmed by Haylock et al. (2006), who also found a change toward wetter conditions in Ecuador and northern Peru, and a decrease in southern Peru. Outgoing longwave radiation (OLR), which is indicative of convective activity and precipitation, shows a significant decrease over the tropical Andes in austral summer (Vuille et al., 2003, 2008). In the outer tropics (south of $10^{\circ} \mathrm{S}$ ) the trend is reversed, featuring an increase in OLR. While these trends are weak and largely insignificant, they are consistent with projected changes in precipitation for the end of the 21st century by the IPCC AR4 model ensemble (Vera et al., 2006).

\section{Methods}

\subsection{Study region}

The PRECIS model is evaluated over the Ecuadorian Andes. In Ecuador, the Andes consists of two parallel, northsouth oriented mountain ranges, separated by the so-called Interandean Valley. This valley is the economic backbone of the country. It hosts major cities such as the capital Quito (around 2 million inhabitants) in the north, and Cuenca (around 500000 inhabitants) further south. Both mountain ranges reach an altitude of typically $4000 \mathrm{~m}$, with some peaks exceeding $6000 \mathrm{~m}$.

The climate in the Ecuadorian Andes is governed by various large-scale climate processes (Vuille et al., 2000). In the south-west, the Pacific Humboldt current provides cool and dry air masses, which lead to a semi-arid climate. Further north along the Pacific coast, a tropical humid climate is induced by the warm and moist air masses advected from the equatorial Pacific. The eastern slopes of the Andes are perennially wet under the influence of the Amazon basin. Finally, the interandean valley is typically drier than the eastern side since most of the air masses have lost their humidity during the orographic uplift on the outer slopes of the Andes. Overall, precipitation patterns are highly variable, ranging from over $3000 \mathrm{~mm}$ on the outer Amazonian slopes to less than $500 \mathrm{~mm}$ in the interandean valley and the south-west Pacific slopes. On interannual time scales precipitation and temperature variability is quite large and dominated primarily by tropical Pacific SST, with El Niño events leading to warmer and drier conditions in most of the Ecuadorian Andes, except for the SW part, while opposite conditions tend to prevail during periods of La Niña (Vuille et al., 2000; Francou et al., 2004).

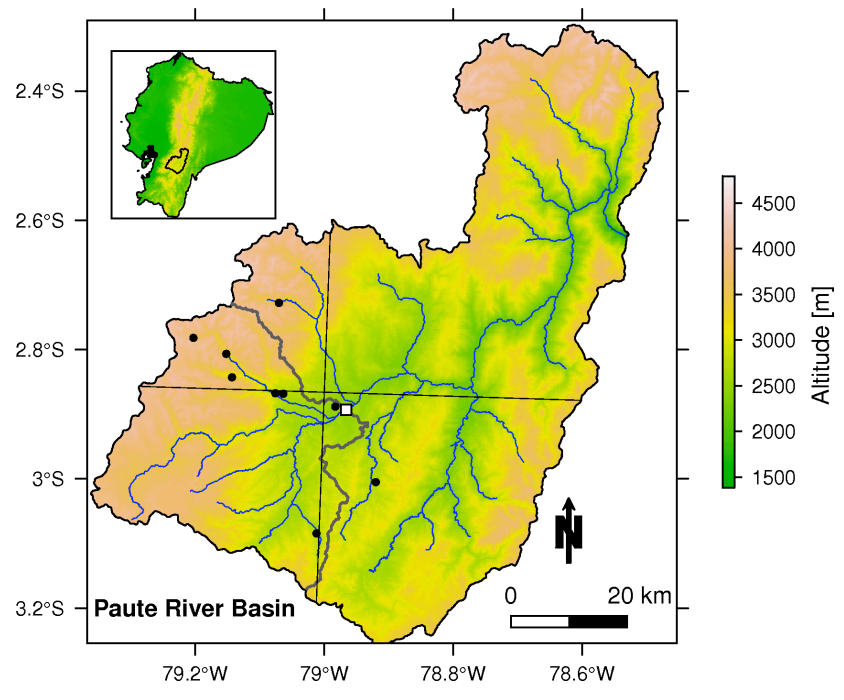

Fig. 1. Location of the Paute river basin and the Tomebamba subbasin (delimited in grey). $\square=$ Discharge station; $\bullet=$ Rain gauges The grid corresponds to the PRECIS pixels.

The study is conducted at two scales. The global and regional climate models are evaluated on a grid that covers Ecuador $\left(75.2-81.1^{\circ} \mathrm{E}, 1.5^{\circ} \mathrm{N}-5^{\circ} \mathrm{S}\right)$. This scale allows for analysing the performance of the climate models over the three major climate regions: the Amazon basin, the Andes and the Pacific coast. The hydrological analysis focuses on the Tomebamba river basin $\left(1250 \mathrm{~km}^{2}\right)$ in the south Ecuadorian Andes. The Tomebamba is a subbasin of the Paute river basin (around $6500 \mathrm{~km}^{2}$, Fig. 1), which hosts the largest hydropower dam in the country (Daniel Palacios, 1075 MW). A second plant was recently opened (Mazar, February 2010). When fully functional, the system can supply up to a $50 \%$ of the country energy needs. Additionally, the Tomebamba river is a major water supplier for the city of Cuenca. As a result, the catchment plays a key role in the socio-economic development of the region and there is an urgent need for adequate climate change adaptation strategies.

\subsection{Modelling}

\subsubsection{Climate modelling}

The GCM ensembles projections for 2070-2099 of TAR and AR4 (IPCC, 2001, 2007) were obtained from the IPCC data repository. The PRECIS model was implemented with the boundary conditions of HadAM3p for the A2 and B2 emission scenarios at a resolution of $50 \mathrm{~km}$. PRECIS is a limitedarea, regional climate model, based on the third generation Hadley Centre RCM (HadRM3) (Jones et al., 2004). A number of studies have used this GCM-RCM configuration for regional 21st century climate change assessments over Central and South America (Garreaud and Falvey, 2009; Karmalkar 
et al., 2008; Marengo et al., 2009; Soares and Marengo, 2009; Urrutia and Vuille, 2009).

The delta method (Fowler et al., 2007) was used to generate time series of future precipitation for the hydrological modelling. In this method, differences between the control and future GCM simulations are applied to historical observations by simple scaling. The delta method was used taking into account seasonality in the change factors, i.e., a scaling factor was calculated for each month of the year.

The delta method makes strong assumptions about the nature of the changes, including a lack of change in the variability and spatial patterns of climate. However, the lack of data and the high variability of the climate system in the region complicate the use of more complex downscaling models.

The future potential evapotranspiration regime was recalculated with the adjusted Thornthwaite relation after adapting the average monthly temperature for future conditions. This method does not take into account the impacts of changes in radiation and humidity on the potential evapotranspiration. However, not all GCMs provide projections for these variables, which would have limited the number of GCMs in the ensemble. We expect that this approach underestimates slightly the range of future streamflow estimates, as models predicting a drier (wetter) future will have a lower (higher) cloud cover and therefore a higher (lower) evapotranspiration. However, it does not affect the conclusions of his paper. For further discussion of the impact of climate change on evapotranspiration and different calculation methods we refer to Kingston et al. (2009).

\subsubsection{Hydrological modelling}

The Tomebamba basin has a complex hydrology. The upper part of the basin is covered with tropical alpine wetlands, covering metamorphic bedrock of low permeability. In the lower parts of the catchment, quaternary deposits with high permeability give rise to ground water aquifers that are thought to contribute significantly to the hydrological response. Although the major hydrological processes in the catchment are reasonably well understood, very little quantitative information is available. Therefore, a detailed representation of these processes in a hydrological model is impossible in view of the available data, and a parsimonious modelling approach was adopted instead.

The model takes precipitation and potential evapotranspiration time series as input, and produces runoff time series in two steps (Beven, 2001). First, a loss module calculates evapotranspiration losses and converts precipitation into effective precipitation (i.e. the part of precipitatation that makes it to streamflow). Second, a routing module representing the delay between precipitation and discharge. In the study region, actual evapotranspiration may be significantly lower than potential evapotranspiration due to soil moisture deficits. Both potential evapotranspiration and soil moisture are strongly dependent on climatological conditions which may change in future scenarios. These changes are accounted for by applying the catchment moisture deficit store of Croke and Jakeman (2004) as a loss module.

For the routing module, two parallel linear stores, for respectively a quick and slow flow component, were implemented (Buytaert et al., 2004; Chapman, 2003; Beven, 2001, p.106). More complex solutions were tested, including autoregression functions and multiple combinations of linear stores, but these configurations did not improve the model performance, while adding additional parameters. The final model has 4 parameters and needs 2 initialisation values.

Potential evapotranspiration was calculated by means of the FAO-Penman Monteith method (Allen et al., 1998), using data from four nearby meteorological stations. To account for altitudinal gradients, the evapotranspiration data were interpolated using a digital elevation map at $50 \mathrm{~m}$ resolution. For the interpolation, the Thornthwaite relation between temperature and potential evapotranspiration was combined with a lapse rate obtained from 24 local temperature stations $\left(-0.54^{\circ} \mathrm{C} 100 \mathrm{~m}^{-1}\right)$ (Timbe, 2004). As the time series for calculating evapotranspiration do not cover the entire modelling region, a monthly climatology was used. For simple hydrological models research has shown that this is generally sufficient (Oudin et al., 2005)

Areal averages of precipitation were obtained from 13 rain gauges (Célleri et al., 2007) using Thiessen interpolation. Some gaps in the rain gauge data were filled using extrapolation from nearby stations using linear regression. Finally, the model was run with a daily timestep for the period from 1978 to 1991 , including a one year spin-up period.

\subsubsection{Hydrological model calibration and uncertainty analysis}

Although a full time series of precipitation data is available, daily discharge data availability for the Tomebamba basin for the study region is only $81 \%$. Therefore the model was run continuously from 1978 to 1991 , but only the simulated discharges that have a corresponding observed discharge were used for model calibration. The hydrological model was calibrated by comparing the simulated and observed discharge directly using the Nash Sutcliffe efficiency and absolute bias. Since our analysis focuses on water resources, the observed and simulated discharge time series were summarised in flow duration curves and average monthly discharge.

A variation of the Generalised Likelihood Uncertainty Estimation method (GLUE, Beven and Binley, 1992) was used for the uncertainty analysis. Using Monte Carlo sampling from uniform prior parameter distributions, $10^{5}$ parameter sets were generated and evaluated using the NashSutcliffe efficiency. Behavioural parameter sets were selected based on a Nash-Sutcliffe threshold, such that the prediction envelope for the flow duration curves and the average monthly discharge bracket the observed flow duration curve and monthly discharge entirely. 

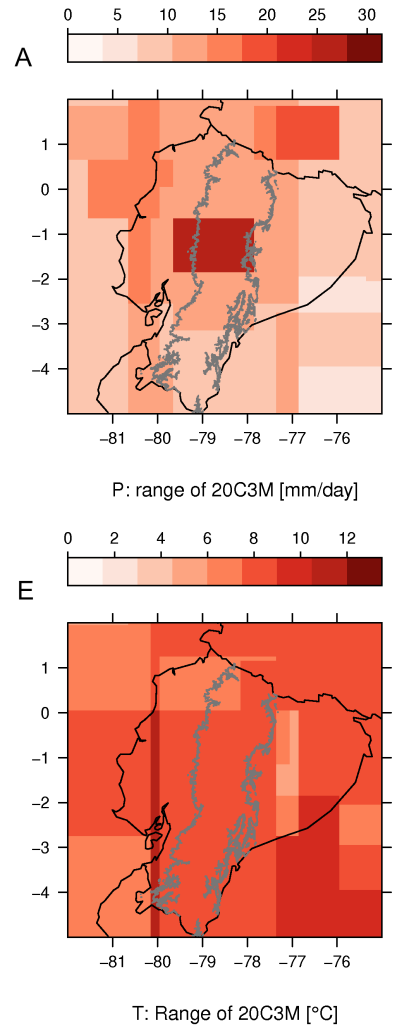
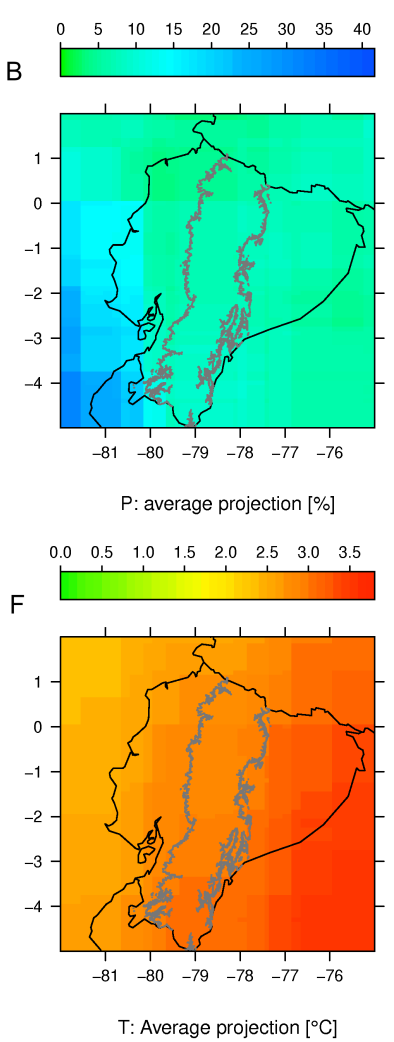
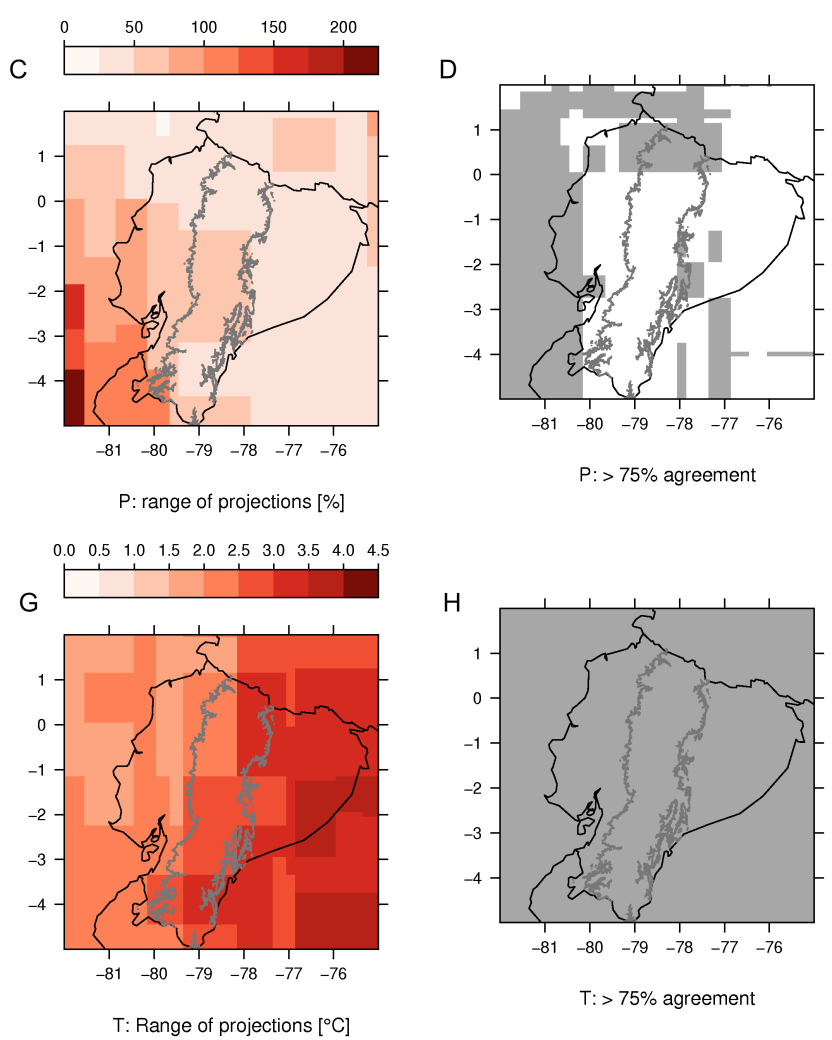

Fig. 2. Average, range and consistency of the GCM simulations of yearly temperature $(T)$ and precipitation $(P)$ in the Ecuadorian Andes. A and E: range of the projections for the twentieth century run (20C3M) during 1961-1990; B and F: average and $\mathbf{C}$ and $\mathbf{G}$ : range of the projected anomalies for the A1B emission scenario (in \% for $P,{ }^{\circ} \mathrm{C}$ for $T$ ) from $20 \mathrm{C} 3 \mathrm{M}$ to the scenario period 2070-2099; D and H: regions where more than $75 \%$ of the models agree on the direction of the change (in grey). The models used in the GCM ensemble are: BCCR-BCM2, CCCMA-CGCM3.1-T47, CCCMA-CGCM3.1-T63, CNRM-CM3, CONS-ECHO-G, CSIRO-MK3, GFDL-CM2, GFDL-CM2.1, INM-CM3, IPSL-CM4, LASG-FGOALS-G1.0, MPIM-ECHAM5, MRI-CGCM2.3.2, NASA-GISS-AOM, NASA-GISSEH, NCAR-CCSM3, NIES-MIROC3.2-HI, NIES-MIROC3.2-MED, UKMO-HADCM3, UKMO-HADGEM1. All models were rescaled to a common resolution of $0.1^{\circ}$ before averaging. The $1000 \mathrm{~m}$ contour line of the Ecuadorian Andes is indicated in grey.

The hydrological model was run with the behavioural parameter sets for the observed period and the future projections of the model ensemble. Finally, 90\% prediction limits were calculated for the flow duration curves and average monthly discharge for the past and future periods.

\section{Results and discussion}

\subsection{Projections}

Figure 2 shows the average and the range of the projected anomalies in annual precipitation and temperature for Ecuador for the A1B emission scenario and the period 20702099. Using the average of the entire IPCC ensemble, an increase in precipitation of around $7.5-10 \%$ is expected over the Ecuadorian Andes (Fig. 2b), together with a temperature increase of around $3{ }^{\circ} \mathrm{C}$ (Fig. 2f).
However, the variation between model projections is considerable. The total disagreement in the magnitude of the precipitation anomalies is often higher than $50 \%$ of annual rainfall (Fig. 2c), while temperature projections range from around 1.5 to $4{ }^{\circ} \mathrm{C}$ (Fig. 2f). In the plots of the projection ranges and model agreement (Fig. 2c and d), the Andes do not stand out as a region with a particularly high model uncertainty. However, in the twentieth century runs for precipitation (Fig. 2a), the Andes region and its surroundings are visible as a region with a higher variation in model simulations compared to the surrounding areas (Pacific Ocean and Amazon basin).

The disagreement among the models in representing the local climate patterns over the Andes may have several underlying causes, but it is likely that differences in resolution are a major factor. Indeed, due to their coarse resolution several GCMs are unable to represent elevation gradients properly, thus neglecting locally important processes such as orographic precipitation and localised convective events. A 


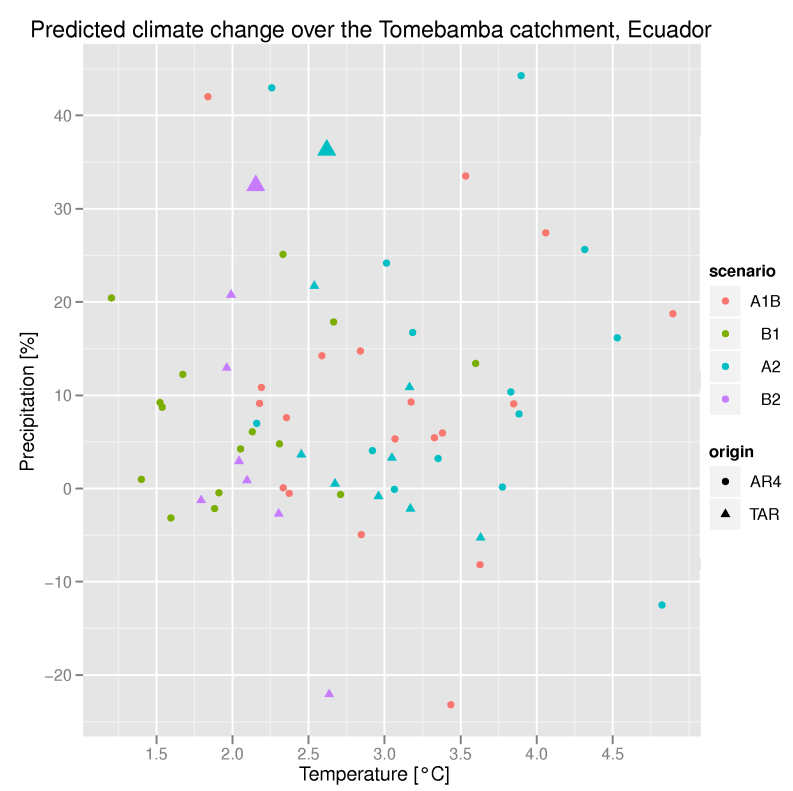

Fig. 3. Overview of the projected anomalies in yearly temperature and relative precipitation for the study area according to climate change assessment report and emission scenario for the period 2070-2099. TAR = IPCC Third Assessment Report (IPCC, 2001); AR4 = IPCC Assessment Report 4 (IPCC, 2007); A1B, A2, B1 and B2 refer to the emission scenarios of the IPCC Special Report on Emissions Scenarios (IPCC, 2001). The larger triangles represent the PRECIS projections.

detailed comparison of the parameterisation schemes of all GCMs would be necessary to understand the mechanisms behind this divergence, which is beyond the scope of this study. However, the fact that GCMs disagree in the representation of current climate poses questions about the reliability of projected anomalies.

At local scale and taking into account other emission scenarios, the variability in projections increases dramatically. For the Tomebamba catchment, projections for the 20702099 period range between a $-25 \%$ and $45 \%$ change in precipitation, and a temperature increase of 1.2 to $4.8^{\circ} \mathrm{C}$ (Fig. 3). Rejecting or reducing the weight of certain emission scenarios or models may be one option to reduce these climate envelopes, but such decisions are subjective and controversial (e.g., Allen and Ingram, 2002; Stainforth et al., 2007b). Alternatively, especially for mountainous regions, downscaling can be explored as a potential pathway to reduce uncertainty.

\subsection{Evaluation of regional downscaling}

This section evaluates the use of PRECIS to improve GCM projections over the Andes. Simulations are selected for the 1961-1990 control run, since they can be evaluated with observational data. It should be noted that a better simulation during the control run does not necessarily indicate a better simulation in future conditions (Stainforth et al., 2007a). We focus on the performance of PRECIS in downscaling precipitation, which is the most important variable for water resources management.

The improved resolution of PRECIS compared to HadAM3p results in a much more complex pattern of current and future precipitation fields (Fig. 4). However, a comparison with the $10 \mathrm{~min}$. observed climatology of New et al. (2000) reveals that this does not necessarily result in improved simulations (Fig. 5).

In general (Fig. 5a), PRECIS underestimates precipitation along the lower Amazonian slopes of the Andes, while precipitation is overestimated at the higher elevations of the Amazonian side of the Andes, consistent with the model validation in Urrutia and Vuille (2009).

The observed displacement between observed and modelled precipitation suggests that PRECIS is incapable of fully capturing the extreme gradient in orographic precipitation that exists along the eastern slope of the Ecuadorian Andes. The overestimation of precipitation along the eastern Andean slope is a problem common to all RCMs and related to excessive orographic uplift due to strong easterly winds (e.g., da Rocha et al., 2009; Insel et al., 2010; Urrutia and Vuille, 2009). It should be kept in mind, however, that the gridded observational precipitation products such as the climatology data have significant uncertainties arising from space-time gaps in the observational records, instrumentation and calibration problems, and sampling inadequacies. This problem is more serious for mountainous regions where the station density is low and interpolation procedures introduce errors (New et al., 1999).

Even if the higher resolution of RCMs may not be sufficient to provide correct localised predictions, a better representation of climate patterns may result in an improved simulation at a regional scale. However, the scale at which such aggregation pays off is strongly dependent on the local climate conditions. Figure 5 investigates in more detail the impact of the scale of aggregation on the accuracy of climate projections for both PRECIS and HadAM3p. The control run of PRECIS and HadAM3p are compared with the observed climatology at three levels of aggregation: the climatology resolution $\left(0.167^{\circ}\right)$, the resolution of PRECIS $\left(0.5^{\circ}\right)$ and the resolution of HadAM3p (1.25 by $1.875^{\circ}$ ) (Fig. 5).

At HadAM3p resolution (Fig. 5c and f) reveals that PRECIS has some potential for improving precipitation simulations slightly, particularly over the Amazon basin where HadAM3p consistently underestimates precipitation. A similar pattern is observed at PRECIS resolution (Fig. 5b and e), although local gradients over the slopes of the Andes play a more pronounced role. This is particularly the case over the Amazonian slope of central Ecuador, where PRECIS overshoots observed precipitation dramatically, thus locally yielding worse results than HadAM3p. Finally, at higher resolution (Fig. 5a and d) the effect is even more pronounced. 

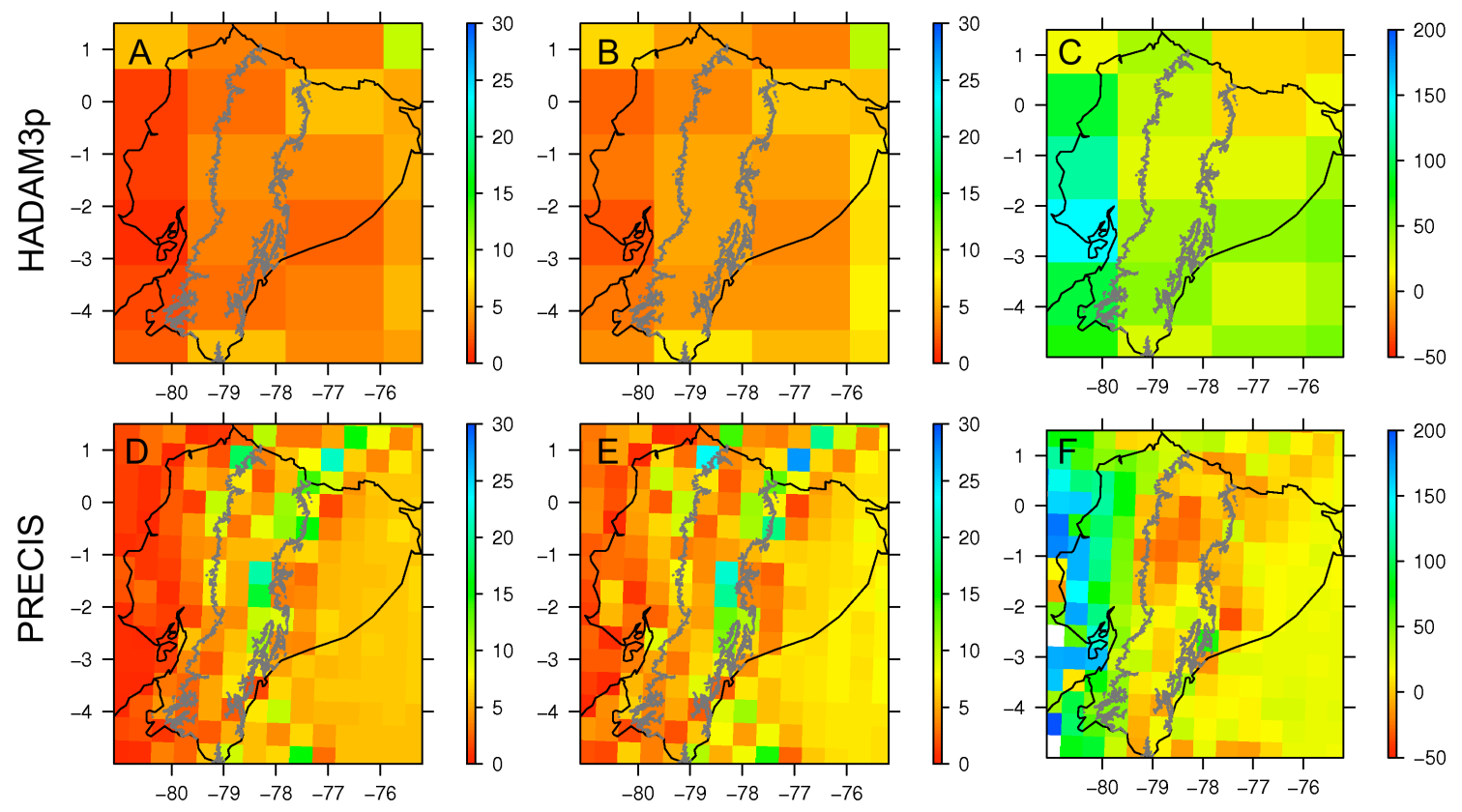

CTRL [mm/day]

2070 - 2099 A2 [mm/day]

anomalies [\%]

Fig. 4. A and B: Modelled average annual precipitation for the control run and future A2 scenario of HadAM $3 p$ (mm/day). C: Relative anomalies in precipitation between the 1961-1990 control run and the 2070-2099 A2 scenario for HadAM3p (\%). D-F: idem for PRECIS. The $1000 \mathrm{~m}$ contour line of the Ecuadorian Andes is indicated in grey.

Both PRECIS and HadAM3p are unable to simulate orographic precipitation along both Andean slopes, with the eastern slope of the central Ecuadorian Andes being particularly problematic. This is indeed a region dominated by strong orographic precipitation.

The results show that resolving high-resolution precipitation gradients in climate models is difficult and potentially risky. Misalignments between simulated and the observed atmospheric processes may result in very poor performance of the regional climate model in certain locations. Such errors are averaged out over larger regions, but may be problematic for local impact assessment where the exact location of precipitation is important.

\subsection{Downscaling in a wider uncertainty context}

Uncertainty in the prediction of future hydrology arises from multiple sources: the GCM climate projections, the downscaling model and the hydrologic model. The route towards lower uncertainty requires an assessment of each. Therefore, we assessed the combined uncertainty in predicting future hydrological conditions in the Tomebamba basin, Ecuador. Figure 6 shows the 90\% uncertainty bounds of predicting the flow duration curve and seasonal variability of river discharge under future climate conditions. This analysis focuses on the A1B scenario, to facilitate comparison with similar efforts elsewhere. The largest share of the uncertainty in future projections (50.8\% for the flow duration curves and 79.2\% for the seasonality) results from the climate model ensemble.

A first approach to decrease this uncertainty would be to improve the GCMs themselves. However, this study shows that a resolution of $50 \mathrm{~km}$, which is the resolution at which PRECIS is implemented, appears to be insufficient to capture the high spatial gradients of precipitation processes in the Andes. Hence, it is unlikely that global models can be sufficiently improved in the near future, and run at resolutions high enough to provide good predictions in these complex environments. Alternatively, a nested approach in which the GCMs are further downscaled with either statistical or dynamical techniques can be pursued. Our evaluation of PRECIS has shown that the use of dynamic models is not without risk. Additionally, such models should be implemented for all GCMs, in order to evaluate the uncertainty envelope of the entire ensemble. This is a challenging task. Another option is to use statistical methods, which are easier to implement. This study used the rudimentary delta method, which, apart from making very strong assumptions, requires the use of highly uncertain precipitation projections from the GCMs. More advanced statistical downscaling methods, such as weather generators (Maraun et al., 2010) relate local precipitation patterns directly to other climate variables such as temperature and sea level pressure. As the latter variables tend to be simulated better by global models, such an approach may reduce the uncertainty of local precipitation 

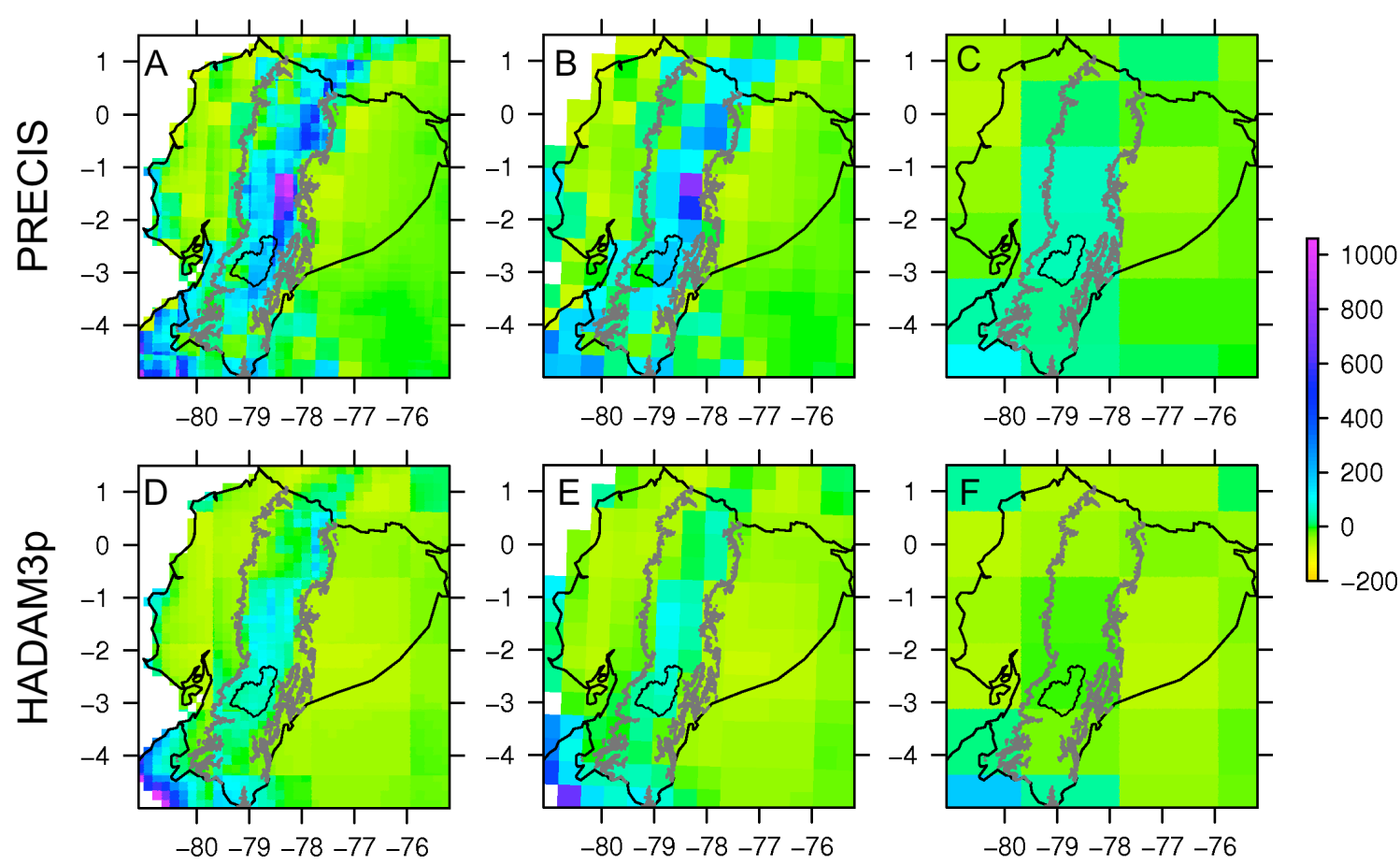

Fig. 5. Bias $(\%)$ of the PRECIS and HadAM3p control run for precipitation compared to the observed climatology at three different resolutions. A and D: climatology resolution $\left(0.167^{\circ}\right)$; $\mathbf{B}$ and E: PRECIS resolution $\left(0.5^{\circ}\right)$; $\mathbf{C}$ and $\mathbf{F}$ : HadAM3p resolution $\left(1.25-1.875^{\circ}\right)$. Note that the actual averaging area of some PRECIS and HadAM3p grid cells is lower due to the unavailability of climatology data over the ocean. The $1000 \mathrm{~m}$ contour line of the Ecuadorian Andes is indicated in grey, and the Paute basin in black.

projections. However, the development and testing of such downscaling models in tropical regions is in its infancy.

The significant contribution of the hydrological model itself to the total uncertainty highlights that apart from improving climate projections, there is also a need for an improved hydrological understanding of the studied system. Previous hydrological research in the area (see Buytaert et al., 2006a, for an overview) has shown that many hydrological processes such as the functioning of local wetlands are still poorly understood.

\subsection{Implications for water resources management}

Looking at the total uncertainty (Fig. 6) the range of potential scenarios is very wide. The potential future conditions bracket the current conditions entirely. Hence, at this moment no decisive conclusions can be drawn about the magnitude or the direction of change of the discharge regime under future climate conditions. The question remains whether such projections are useful for water resources management. Water managers usually turn to scientists for updates on the latest certainties. An important implication of these and similar results (e.g., Dessai and Hulme, 2007) is that it might be wiser to turn to scientists for updates on the range of uncertainties for climate change impact questions. The regional climate change projections do not provide reliable estimates of future precipitation patterns at a local scale, which are needed to optimise water management strategies. They provide information about the range of uncertainties and if anything, the range of plausible precipitation scenarios only broadens when climate change impacts are taken into account. While additional research can probably reduce the range of plausible scenarios somewhat, important uncertainties are unlikely to be eliminated in the foreseeable future. Still, adaptation decisions need to be taken now.

So, when optimising water management based on future precipitation projections that are riddled with uncertainties, what is the relevance of these modelling efforts for sustainable water management? Developments in climate adaptation and water management research present a number of different approaches to uncertainties and decision making. Adaptive water management (Pahl-Wostl, 2007) starts from the acceptance of irreducible uncertainties about future (climatic) changes. Assuming future changes and irreducible uncertainties about the direction and timing of these changes, adaptive management approaches move away from a "predict-and-control" paradigm, towards a more adaptive approach, with continuous learning and flexibility as key aims. In this sense, infrastructural investments with high sunk costs, irreversible decisions, or fixed management strategies prevent continuous learning and adjustment. A more effective way of dealing with unpredictability is to avoid control by creating the capacity to respond effectively to changing and unknown conditions, through 

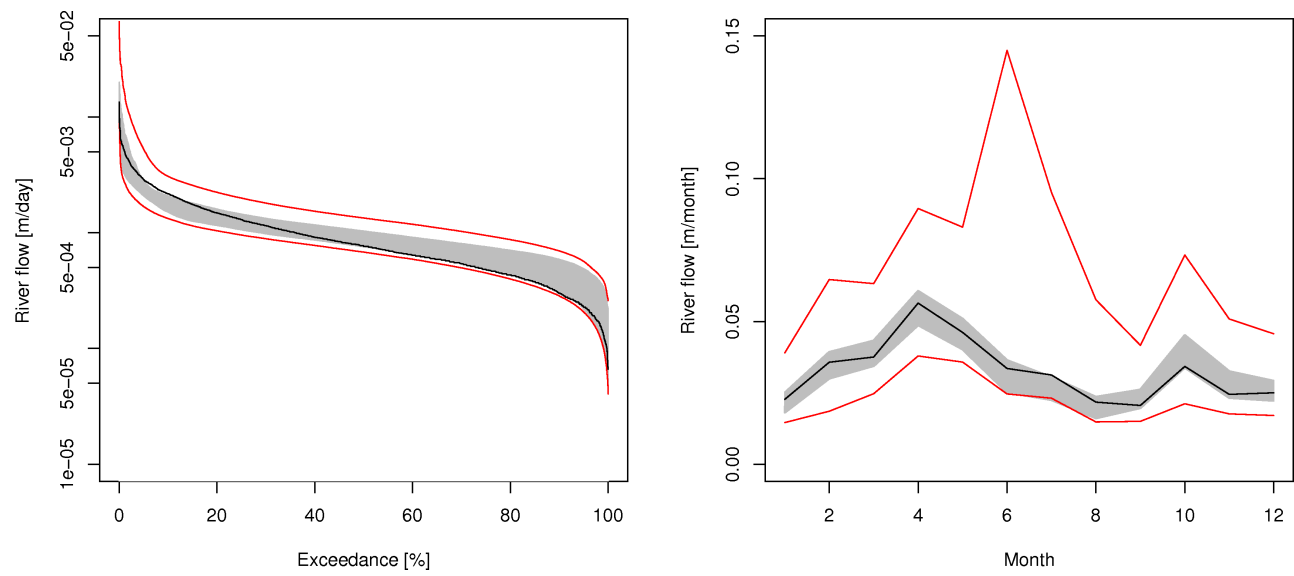

Fig. 6. Uncertainty in the projections of climate change impacts on water resources. Left: flow duration curve; right: mean monthly discharge. The black line is the observed curve, the grey area indicates the $90 \%$ uncertainty bounds of the hydrological model during calibration, the red lines indicate the $90 \%$ prediction limits for the future scenario (A1B, 2070-2099), including hydrological model and GCM uncertainty.

developing strategies that are robust under the full range of possible future scenarios, through diversification of strategies or through strategies that can be flexibly applied when needed (Brugnach et al., 2008). The call for robust strategies can be complemented with a focus on the key vulnerabilities of the water system and the services it provides, rather than on the optimal strategy (Dessai et al., 2009). Evidence on the range of plausible representations of future climate then becomes highly instrumental for identifying and addressing these vulnerabilities, in order to avoid that the water system would fail to provide the critical minimum of services. A related approach is the development of "no regret" interventions, defined as strategies that yield benefits regardless of future trends in climate scenarios (Heltberg et al., 2009). Given that climate is only one of the many uncertain processes that influence water resources management, "no regret" strategies will favour measures that are beneficial for these other domains as well.

These strategies are ideally the outcome of an integrated approach involving scientists, resource managers and stakeholders. In the Paute basin, such interactions have been ongoing for a long time. Two key ecosystems, Andean forests and alpine wetlands, have been identified as excellent water providers due to their high water storage and regulation capacity. Adaptation efforts have therefore focused on an improved management and conservation of these ecosystems (Célleri and Feyen, 2009). Similarly, erosion control and restoration of degraded agricultural fields in the lower areas of the Paute basin intend to lower the agricultural pressure on water resource areas (Dercon et al., 2006).

\section{Conclusions}

This study is concerned with the usefulness of RCMs for downscaling global climate projections for regional water management in the Ecuadorian Andes. Global circulation models project an increase in temperature (around $3{ }^{\circ} \mathrm{C}$, Fig. 2b) and precipitation (around 10\%, Fig. 2f) over the Ecuadorian Andes. The uncertainty in the projections, quantified by the ensemble projection range, is similar to the adjacent Amazon and Pacific regions. However, the Andes stand out as a region of high uncertainty during the twentieth century run (20C3M, Fig. 2a), casting doubt over the reliability of future projections.

The evaluation of the RCM PRECIS over the tropical Andes gave mixed results (Fig. 5). Compared to HadAM3p, which provided the boundary conditions of the PRECIS implementation, PRECIS is able to simulate total precipitation better over the Amazon basin. However, large errors in the simulation of precipitation patterns appear over the Andes when the model is compared to observational data. Locally, they can overshoot the error in the coarse resolution HadAM3p model. The results show that at least for some regions and scales of aggregation, regional climate models such as PRECIS may be instrumental in improving the simulations of global climate models. However, the conditions for such improvement should be very carefully analysed. For local climate, RCMs may produce as inappropriate or worse results compared with GCMs, especially when precipitation is considered. For most other variables that are elevation dependent (e.g., temperature), the better vertical resolution of RCMs does, however, yield a significant improvement over GCMs (Urrutia and Vuille, 2009). Biases in precipitation projections at the regional scale are nonetheless problematic as this is very often the scale at which water management is implemented, especially in tropical regions (e.g., small scale 
irrigation schemes). Also for many larger watersheds, providing mean areal averages of precipitation (as in Fig. 5c and $f$ ) is often insufficient. Especially in hydrologically heterogeneous regions such as the Andes, the exact location of precipitation is very important. For instance, high altitudinal wetlands have a very different hydrological response than the degraded, steep slopes of the interandean valley (e.g., Buytaert et al., 2006a)

It should be noted, however, that observed climatologies themselves are prone to large uncertainties. Also, this paper analysed only yearly means. The comparison of the representation of seasonality in PRECIS is the topic of further research.

The question remains to which extent these results can be extrapolated to other regions. The Ecuadorian Andes is a region with extreme gradients in precipitation, and a surface water dominated hydrology with limited buffering capacity. Similar regions, such as the rest of the northern Andes and other tropical mountain regions, may experience similar problems. However, in glaciated or snowmelt dominated regions (including much of the outer tropical and subtropical Andes) with a long dry season the situation can be quite different. Here, changes in temperature are more important as they drive glacier and snowmelt. It is expected that during the dry season no large changes in precipitation will occur and that temperature changes will be the most important driver of changes in water resources. This can only be realistically investigated with RCMs due to the elevation dependence of projected temperature changes.

Finally, this study evaluated only one RCM driven by one GCM. Other combinations may give very different results. In order to evaluate whether RCMs indeed decrease the entire projection envelope of precipitation, it is necessary to implement RCMs for the entire GCM ensemble. Such efforts are currently ongoing (e.g., the CORDEX experiment). However, at least for some regions it may be that uncertainty will not reduce sufficiently in the near future to translate climate projections into hydrological projections that are of direct relevance for local water resources management. In such areas, adaptation strategies should focus on decreasing the vulnerabilities and increasing the robustness of current supply systems.

Acknowledgements. We would like to thank Gregory Greenwood from the Mountain Research Initiative and Daniel Viviroli of the University of Bern for organising the workshop on "Climate change and water resources management in mountains" in September 2009, and for editing the special issue. WB was supported by a Royal Geographical Society RGS-IBG Small Research Grant. MV acknowledges funding through NSF-awards EAR-0519415 and EAR-0836215. RC was supported by SENACYT PIC-08-460 grant. We acknowledge the research institutes that provided access to climate model projections through the IPCC Data Distribution Centre (http://www.ipcc-data.org/).

Edited by: G. Greenwood

\section{References}

Allen, M. R. and Ingram, W. J.: Constraints on future changes in climate and the hydrologic cycle, Nature, 419, 224-232, 2002.

Allen, R. G., Pereira, L. S., Raes, D., and Smith, M.: Crop evapotranspiration. Guidelines for computing crop water requirements, FAO Irrigation and Drainage Paper 56, FAO, Rome, 1998.

Bates, B. C., Kundzewicz, Z. W., Wu, S., and Palutikof, J.: Climate Change and Water. Technical Paper of the Intergovernmental Panel on Climate Change, IPCC Secretariat, Geneva, 2008.

Beniston, M.: Climate change in mountain regions: a review of possible impacts, Climatic Change, 59, 5-31, 2003.

Beven, K. and Binley, A.: The Future of Distributed Models: Model Calibration and Uncertainty Prediction, Hydrol. Process., 6, 279-298, 1992.

Beven, K. J.: Rainfall-runoff modelling. The primer, John Wiley \& Sons, Chichester, 2001.

Bradley, R. S., Vuille, M., Diaz, H. F., and Vergara, W.: Threats to water supplies in the tropical Andes, Science, 312, 1755-1756, 2006.

Bradley, R. S., Keimig, F. T., Diaz, H. F., and Hardy, D. R.: Recent changes in freezing level heights in the tropics with implications for the deglacierization of high mountain regions, Geophys. Res. Lett., 36, L17701, doi:10.1029/2009GL037712, 2009.

Brugnach, M., Dewulf, A. R. P. J., Pahl-Wostl, C., and Taillieu, T.: Toward a relational concept of uncertainty: about knowing too little, knowing too differently, and accepting not to know, Ecol. Soc., 13, 30, 2008.

Buytaert, W., De Bivre, B., Wyseure, G., and Deckers, J.: The use of the linear reservoir concept to quantify the impact of changes in land use on the hydrology of catchments in the Andes, Hydrol. Earth Syst. Sci., 8, 108-114, doi:10.5194/hess-8-108-2004, 2004.

Buytaert, W., Célleri, R., De Bièvre, B., Hofstede, R., Cisneros, F., Wyseure, G., and Deckers, J.: Human impact on the hydrology of the Andean páramos, Earth-Sci. Rev., 79, 53-72, 2006 a.

Buytaert, W., Célleri, R., Willems, P., De Bièvre, B., and Wyseure, G.: Spatial and temporal rainfall variability in mountainous areas: A case study from the south Ecuadorian Andes, J. Hydrol., 329, 413-421, 2006b.

Buytaert, W., Célleri, R., and Timbe, L.: Predicting climate change impacts on water resources in the tropical Andes: the effects of GCM uncertainty, Geophys. Res. Lett., 36, L07406, doi:10.1029/2008GL037048, 2009.

Célleri, R. and Feyen, J.: The Hydrology of Tropical Andean Ecosystems: Importance, Knowledge Status, and Perspectives, Mt. Res. Dev., 29, 350-355, 2009.

Célleri, R., Willems, P., Buytaert, W., and Feyen, J.: Space-time variability of rainfall in the Paute River basin of South Ecuador, Hydrol. Process., 21, 3316-3327, 2007.

Chapman, T. G.: Modelling stream recession flows, Environ. Modell. Softw., 18, 683-692, 2003.

Croke, B. and Jakeman, A.: A catchment moisture deficit module for the IHACRES rainfall-runoff model, Environ. Modell. Softw., 19, 1-5, 2004.

da Rocha, R. P., Morales, C. A., Cuadra, S. V., and Ambrizzi, T.: Precipitation diurnal cycle and summer climatology assessment over South America: An evaluation of Regional Climate Model version 3 simulations, J. Geophys. Res., 114, D10108, doi:10.1029/2008JD010212, 2009. 
Dercon, G., Govers, G., Poesen, J., Sánchez, H., Rombaut, K., Vandenbroeck, E., Loaiza, G., and Deckers, J.: Animal-powered tillage erosion assessment in the southern Andes region of Ecuador, Geomorphology, 87, 4-15, 2006.

Dessai, S. and Hulme, M.: Assessing the robustness of adaptation decisions to climate change uncertainties: A case study on water resources management in the East of England, Global Environ. Chang., 17, 59-72, 2007.

Dessai, S., Hulme, M., Lempert, R., and Pielke Jr, R.: Climate prediction: a limit to adaptation?, in: Adapting to Climate Change: Thresholds, Values, Governance, edited by: Adger, W. N., Lorenzoni, I., and O'Brien, K., 64-78, Cambridge University Press, Cambridge, 2009.

Diaz, H. F., Duncan, J. K. E. C., and Bradley, R. S.: Variability of freezing levels, melting season indicators and snow cover for selected high elevation and continental regions in the last 50 years, Climatic Change, 59, 33-52, 2003.

Fowler, H. J., Blenkinsop, S., and Tebaldi, C.: Linking climate change modelling to impacts studies: recent advances in downscaling techniques for hydrological modelling, Int. J. Climatol., 27, 1547-1578, 2007.

Francou, B., Vuille, M., Favier, V., and Cáceres, B.: New evidence for an ENSO impact on low-latitude glaciers: Antizana 15, Andes of Ecuador, $0^{\circ} 28$ 'S, J. Geophys. Res., 109, D18106, doi: 10.1029/2003JD004484, 2004.

Garreaud, R. and Falvey, M.: The coastal winds off western subtropical South America in future climate scenarios, Int. J. Climatol., 29, 543-554, doi:10.1002/joc.1716, 2009.

Haylock, M. R., Peterson, T. C., Alves, L. M., Ambrizzi, T., Anunciacao, M. T., Baez, J., Barros, V. R., Berlato, M. A., Bidegain, M., Coronel, G., Corradi, V., Garcia, V. J., Grimm, A. M., Karoly, D., Marengo, J. A., Marino, M. B., Moncunilland, D. F., Nechet, D., Quintana, J., Rebello, E., Rusticucci, M., Santos, J. L., Trebejo, I., and Vincent, L. A.: Trends in total and extreme South American rainfall in 1960-2000 and links with sea surface temperature, J. Climate, 19, 1490-1512, 2006.

Heltberg, R., Siegel, P. B., and Jorgensen, S. L.: Addressing human vulnerability to climate change: Toward a 'no-regrets' approach, Global Environ.1 Chang., 19, 89-99, 2009.

Insel, N., Poulsen, C. J., and Ehlers, T. A.: Influence of the Andes mountains on South American moisture transport, convection and precipitation, Clim. Dynam., in press, doi:10.1007/ s00382-009-0637-1, 2010.

IPCC: Climate Change 2001: Impacts, Adaptation and Vulnerability, Cambridge University Press, Cambridge, 2001.

IPCC: Climate Change 2007 - Impacts, Adaptation and Vulnerability, Cambridge University Press, Cambridge, 2007.

Jones, R. G., Noguer, M., Hassell, D., Hudson, D., Wilson, S., Jenkins, G., and Mitchell, J.: Generating high resolution climate change scenarios using PRECIS, Met Office Hadley Centre, Exeter, 2004.

Karmalkar, A. V., Bradley, R. S., and Diaz, H. F.: Climate change scenario for Costa Rican montane forests, Geophys. Res. Lett., 35, L11702, doi:10.1029/2008GL033940, 2008.

Kingston, D. G., Todd, M. C., Taylor, R. G., Thompson, J. R., and Arnell, N. W.: Uncertainty in the estimation of potential evapotranspiration under climate change, Geophys. Res. Lett., 36, L20403, doi:10.1029/2009GL040267, 2009.
Maraun, D., Wetterhall, F., Ireson, A. M., Chandler, R. E., Kendon, E. J., Widmann, M., Brienen, S., Rust, H. W., Sauter, T., Themeß1, M., Venema, V. K. C., Chun, K. P., Goodess, C. M., Jones, R. G., Onof, C., Vrac, M., and Thiele-Eich, I.: Precipitation downscaling under climate change. Recent developments to bridge the gap between dynamical models and the end user, Rev. Geophys., in press, doi:10.1029/2009RG000314, 2010.

Marengo, J. A., Jones, R., Alves, L. M., and Valverde, M. C.: Future change of temperature and precipitation extremes in South America as derived from the PRECIS regional climate modeling system, Int. J. Climatol., 29, 2241-2255, 2009.

New, M., Hulme, M., and Jones, P.: Representing twentieth-century space-time climate variability. Part I: Development of a 1961-90 mean monthly terrestrial climatology, J. Climate, 12, 829-856, 1999.

New, M., Lister, D., Hulme, M., and Makin, I.: A high-resolution data set of surface climate over global land areas, Clim. Res., 21, $1-25,2000$.

Oudin, L., Michel, C., and Anctil, F.: Which potential evapotranspiration input for a lumped rainfall-runoff model? Part 1, Can rainfall-runoff models effectively handle detailed potential evapotranspiration inputs?, J. Hydrology, 303, 275-289, 2005.

Pahl-Wostl, C.: Transitions towards adaptive management of water facing climate and global change, Water Resour. Manag., 21, 4962, 2007.

Soares, W. R. and Marengo, J. A.: Assesments of moisture fluxes east of the Andes in South America in a global warming scenario, Int. J. Climatol., 29, 1395-1414, 2009.

Stainforth, D. A., Allen, M. R., Tredger, E. R., and Smith, L. A.: Confidence, uncertainty and decision-support relevance in climate predictions, Philos. T. R. Soc. A, 365, 2145-2161, 2007a.

Stainforth, D. A., Downing, T. E., Washington, R., Lopez, A., and New, M.: Issues in the interpretation of climate model ensembles to inform decisions, Philos. T. R. Soc. A, 365, 2163-2177, 2007b.

Still, C. J., Foster, P. N., and Schneider, S. H.: Simulating the effects of climate change on tropical montane cloud forests, Nature, 398, 608-610, 1999.

Timbe, E.: Disgregacion temporal de datos diarios de precipitacion en microcuencas de páramo, Master's thesis, Universidad de Cuenca, 2004.

Urrutia, R. and Vuille, M.: Climate change projections for the tropical Andes using a regional climate model: Temperature and precipitation simulations for the end of the 21st century, J. Geophys. Res., 114, D02108, doi:10.1029/2008JD011021, 2009.

Vera, C., Silvestri, G., Liebmann, B., and Gonzalez, P.: Climate change scenarios for seasonal precipitation in South America from IPCC-AR4 models, Geophys. Res. Lett., 33, L13707, doi: 10.1029/2006GL025759, 2006.

Viviroli, D., Archer, D. R., Buytaert, W., Fowler, H. J., Greenwood, G. B., Hamlet, A. F., Huang, Y., Koboltschnig, G., Litaor, M. I., López-Moreno, J. I., Lorentz, S., Schädler, B., Schwaiger, K., Vuille, M., and Woods, R.: Climate change and mountain water resources: overview and recommendations for research, management and politics, Hydrol. Earth Syst. Sci. Discuss., 7, 2829-2895, doi:10.5194/hessd-7-2829-2010, 2010. 
Vuille, M., Bradley, R. S., and Keimig, F.: Climate variability in the Andes of Ecuador and its relation to tropical Pacific and Atlantic sea surface temperature anomalies, J. Climate, 13, 2520-2535, 2000.

Vuille, M., Bradley, R. S., Werner, M., and Keimig, F.: 20th century climate change in the tropical Andes: observations and model results, Climatic Change, 59, 75-99, 2003.
Vuille, M., Francou, B., Wagnon, P., Juen, I., Kaser, G., Mark, B. G., and Bradley, R. S.: Climate change and tropical Andean glaciers: Past, present and future, Earth-Sci. Rev., 89, 79-96, doi:10.1016/j.earscirev.2008.04.002, 2008.

World Meteorological Organisation: Guide to Hydrological practices, WMO Publication 168, WMO, Switzerland, 1995. 